\title{
8
}

\section{Gains for Trade in Services in an EU-Australia Free Trade Agreement: A European Perspective}

\section{Pascal Kerneis}

The European Union (EU) and Australia are like-minded partners who share many common concerns in today's international trade environment, such as the initiatives to further liberalise the trade of goods and services and advance the Trade in Services Agreement (TiSA) that is currently under discussion. This chapter will discuss the common interests and then assess the potential content of an EU-Australia free trade agreement (FTA) that may benefit companies operating in the services sectors. It will analyse the traditional elements of market access related to the trade in services, and also the key concerns for services companies that seek to maximise their returns on the basis of a modern trade agreement, particularly where the agreement may cover issues of investment, public procurement and regulatory cooperation. 


\section{Services in the EU-Australia trade relationship}

It is essential to demonstrate the importance of trade in services between the EU and Australia, in particular since, for too long, the bilateral trade discussions have been dominated in the political arena by the issues of agricultural trade, notably in the context of the World Trade Organization (WTO). Currently, Australia and the EU maintain close economic relations. In 2013, Australia ranked as the 15th-largest trade in goods partner of the EU, while the EU was Australia's third-largest trading partner after China and Japan. Total bilateral trade in goods that year amounted to $€ 42.3$ billion (Eurostat 2015). Traditionally, Australia's exports to the EU have been dominated by minerals (fuels and mining products) and agricultural products, while the EU's exports to Australia are predominantly manufactured goods. But services have become an important and growing part of the EU-Australia trade relationship. In 2013, total trade in commercial services amounted to $€ 27.0$ billion and represented 39 per cent of the total bilateral trade (Eurostat 2015). This is a significant increase from a share of 26 per cent in 2000, as Figure 1 shows, and demonstrates that the bilateral trade of services has increased faster than the trade of goods. It is also higher than the 20 per cent average share of trade in services in 2014 global trade (WTO 2015: Tables A4 and A5), and underlines that trade in services now plays an important role in this bilateral trade relationship.

The EU and Australia conduct their trade and economic relations under multilateral agreements to which both are signatories, such as the General Agreement on Tariffs and Trade (GATT) and the General Agreement on Trade in Services (GATS). Both also cooperated in the Doha Round of multilateral discussions on various issues that impact on bilateral trade, including services trade. The Doha Round has not yet been completed, but it has offered an opportunity to build consensus between the EU and Australia and to establish a foundation for further discussions about bilateral trade. In addition, the EU-Australia Partnership Framework of October 2008 has relevance for the EU-Australia trade relations. Although most of its clauses do not relate to issues of trade, the framework expresses a commitment to further cooperation including on trade issues. It is most explicit about reconfirming the bilateral mutual recognition agreement (MRA), which was revised a year later. Although the scope 
of this agreement is largely limited to mutual recognition of testing procedures that apply to certain products traded bilaterally, it leaves open opportunities to expand areas of mutual recognition in the future.

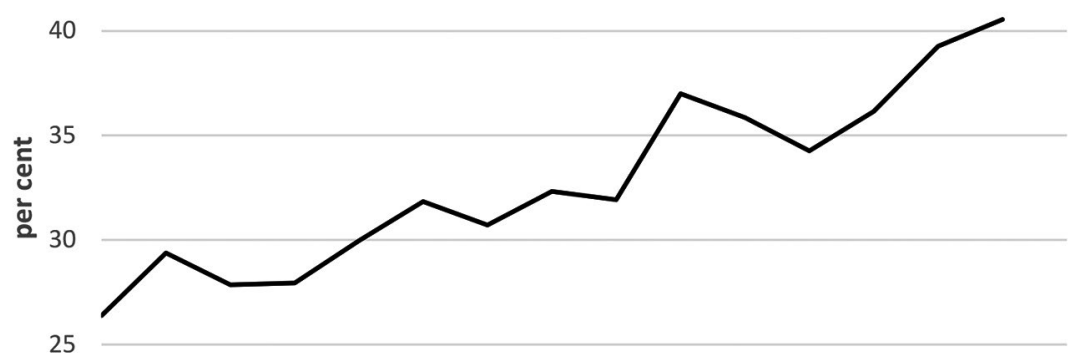

20

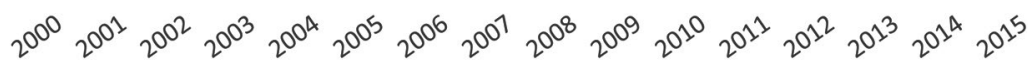

Figure 1. Share of services in the EU's total bilateral trade with Australia, 2000-13

Note: Total trade includes imports and exports.

Source: Calculated from Eurostat 2015.

The world economy is increasingly dependent on services. According to the WTO, international trade in services (excluding intra-EU trade) reached over US\$3.7 trillion in 2014 (WTO 2015: Table 1.10). The value of international services trade has increased faster than the trade of goods during 2004-2014 (WTO 2015: Tables A4 and A5). Services provide essential components in all global supply chains and represent a growing share of the value added embodied in traded goods. Indeed, according to the WTO and the Organisation for Economic Co-operation and Development (OECD), global trade in services represents approximately one-quarter of global trade in terms of the value of final products, but nearly half of global trade in terms of the international trade in value added (TiVA) associated with these goods (OECD 2015).

This phenomenon is a consequence of the increasing internationalisation of supply chains, which not only involves semi-manufactured goods, but importantly also a wide range of services. In turn, this development is related to the rise of knowledge-based activities and the growing importance of intangible assets in all economies, together with the development 
of internet-based communications and applications, and the enhanced interplay between the services and the manufacturing and agricultural sectors. Major advances in computer networks, telecommunications, express delivery and air transportation have contributed this economic shift. These changes have provided the platform for raising countless small and large services companies from local establishments to international businesses. Together they are now creating millions of jobs worldwide.

The EU is by far the biggest exporter (€831 billion in 2015) and importer (€685 billion in 2015) of services in the world, with a significant positive trade balance of $€ 146$ billion (Eurostat 2017). The EU is also the world's biggest investor in services sectors, with nearly 60 per cent of its total outward foreign direct investment (FDI) directed at services sectors. ${ }^{1}$

\section{Services components in the EU-Australia FTA: Building on TiSA}

The EU-Australia FTA should be an ambitious and balanced, deep and comprehensive agreement. It should include provisions on all the key subjects: trade in goods and services, investment, intellectual property rights, public procurement, competition policy and dispute settlement. It should also contain provisions that allow for further consultation and cooperation with an eye to future regulatory reforms. Concerning the goods-related issues, the agreement should aim at removing tariffs with only few exceptions and should address non-tariff barriers and rules of origin issues. It should also look at possibilities to set up regulatory cooperation processes aiming at convergence of product standards and certification.

It will be important for the two negotiating parties to ensure that this FTA will deliver the best possible market openings for firms and establish rules that encourage firms to increase their bilateral activities. To that end, Australia will most likely look closely at the Comprehensive Economic and Trade Agreement (CETA), which the EU has negotiated with Canada in 2013, and which is currently the benchmark for FTAs with the EU. In turn, the EU will have a close look at the commitments Australia has made in its recent FTAs, including the content of the Australia-Korea

$1 € 3.5$ trillion out of $€ 6$ trillion of extra-EU outward FDI stocks in 2014 (Eurostat 2017). 
FTA, the Australia-Japan FTA and the China-Australia FTA, concluded in 2014, and the Trans-Pacific Partnership (TPP) in which Australia participates, concluded in October 2015. Despite the fact that the US decided to withdraw from TPP in January 2017, the text of this agreement remains a benchmark and an implementation of the agreement with the other 11 partners is still possible.

The rest of this chapter will address the possible content of an EUAustralia FTA as it applies to services companies. The chapter will discuss the market access pillar, including all modes of supply and access to the public procurement market, and then the regulatory cooperation and other rules that the agreement should include to be a really 'deep and comprehensive' FTA, as the EU prefers to label the 'new generation' or 'WTO-plus' FTAs it seeks to pursue.

To begin with, to have a real added value, the EU-Australia FTA should go beyond all aspects of the TiSA, which is currently still under negotiation. The fate of TiSA is uncertain after the cancellation of a TiSA Ministerial meeting on 9 November, one day after the US presidential elections. The ministerial was scheduled beginning of December 2016 to try to conclude the talks. However, parties agreed to keep all texts and offers as a starting point for any further resuming talks in due time. This chapter will therefore briefly discuss the TiSA and its components, before analysing in more detail the possible relevant elements of the bilateral agreement for services companies.

With the impasse in WTO negotiations in the Doha Round with respect to services, the idea of moving the trade agenda forward through a standalone agreement on trade in services was proposed in 2012. The process was an initiative of Australia and the United States of America (USA) and it was proposed to a group of countries that met in Geneva under the moniker the 'Really Good Friends of Services' (Vastine 2005). These countries took the initiative to craft the TiSA, which is currently being negotiated by 23 members of the WTO (or 50 countries in all, including all individual EU member countries). ${ }^{2}$ Together, these countries account for approximately 70 per cent of world trade in services.

2 Australia, Canada, Chile, Taiwan, Colombia, Costa Rica, EU, Hong Kong, Iceland, Israel, Japan, Korea, Liechtenstein, Mauritius, Mexico, New Zealand, Norway, Pakistan, Panama, Peru, Switzerland, Turkey, USA. 
Since April 2013, TiSA participants completed 21 negotiating rounds on the core text of the agreement. Relevant topics include domestic regulation, transparency, entry of business persons and sector-specific negotiations focusing on the new and enhanced trade rules for, inter alia, e-commerce and telecommunications, financial services, professional services, air and maritime transportation, information and communications technology (ICT) services and energy services. Regarding the market access pillar of the talks, participating countries have confirmed that they will use a 'hybrid approach', where commitments in the TiSA market access schedule will use a 'positive list' approach, meaning that only the services listed on the schedule are to be liberalised. In contrast, the national treatment commitments will be scheduled on a 'negative list' basis, which means that for any services where a party does not commit to apply full national treatment, a reservation must be listed (Broude \& Moses 2016).

The countries participating in TiSA decided to start market access discussions by agreeing to table the highest level of commitment expressed by each party under its best (implemented) FTA at the date when negotiations started. However, the aim of TiSA is not to simply repackage existing commitments in completed FTAs, but to create genuine new opportunities through new market access commitments that go beyond current openness. For example, firms aim to provide the best customised service to their clients. An essential aspect of this commitment is 'talent mobility', the ability to move highly skilled services personnel rapidly to international locations where firms require their acumen (OECD 2008). The TiSA seeks to address this important issue of talent mobility to allow market access to service providers in a predictable and expedited way across all participating countries.

In almost every country the majority of the services sectors are subject to strict rules and regulations that govern their daily functioning, such as licensing and authorisation requirements, competition rules, product quality requirements and consumer protection. TiSA offers an opportunity to draft horizontal disciplinary provisions for the issues that are likely to become new challenges in the 21 st century, such as crossborder data flows, forced localisation, and the conditions under which state-owned and state-sponsored enterprises compete in international commercial markets. 


\section{Going beyond TiSA: EU-Australia market access}

Taking these elements into consideration and accepting that the EUAustralia FTA will want to go beyond the TiSA, what should be added? In short, to facilitate the bilateral trade of services further, the agreement should aim at facilitating cross-border trade in services and movement of people by removing remaining market access barriers of all kinds to the maximum degree possible. The question is, what degree is possible?

Many services are traded across borders as a consequence of serviceproviding firms investing in the establishment of a commercial presence in the form of a foreign subsidiary company. Ideally, the FTA should provide pre-establishment market access in all economic sectors, including in all services sectors. It should also offer post-establishment protection that sets clear protection for firms establishing foreign subsidiaries through FDI and puts into place a state-of-the-art investor-state dispute settlement (ISDS) mechanism (e.g. Bronkers 2015; Nottage 2015).

In addition, the FTA should also contain an intellectual property rights section that addresses the relevant issues related to copyright of software and patents of hardware used by services companies such as in ICT, energy, water and waste management, etc., as well as related to the transfer of data. The agreement should also ensure better mutual access to public procurement, including for services sectors in all public entities (Adlung \& Mamdouh 2014: 203; Sheffler 2015). And the FTA should include chapters on rules, such as establishing a regulatory cooperation mechanism, provisions on competition and sustainable development, and a state-to-state dispute settlement body.

It must be remembered that the starting point of discussions about issues related to market access for services is the 1994 GATS, particularly Article XVI. An EU-Australia FTA would be a historical opportunity to substantially improve Australia's market access to the EU. Hence, the market access pillar in a bilateral FTA should be ambitious. If possible, it should correspond to a GATS + TiSA, or a GATS + TPP arrangement. To achieve this, the FTA should remove all caps on equity, although possibly with negotiated exceptions. It should also bind the practices that go beyond existing commitments (i.e. higher market access than in 
existing FTAs), and FTA negotiations should seriously consider removing existing barriers, so as to effectively create new market opportunities for service providers from both sides.

As in CETA, the FTA should include so-called 'standstill' and 'ratchet' clauses (Adlung \& Mamdouh 2014: 200-1) to ensure that parties to the agreement will not revert to trade legislation and regulation that was in place at the time of the signing of the agreement, unless provided for in the agreement. This would warrant the spreading of trade liberalisation on a non-discriminatory basis after a party to the agreement has unilaterally decided to open up the market. The FTA should be particularly ambitious in the sectors of professional services, telecommunication services, postal and express services, and financial services that are often left behind in such negotiations.

The scheduling of market access and national treatment commitments should follow the negative list approach. A schedule of commitments undertaken under the negative list approach would simply provide a much better visibility for a company, clear indications of what it cannot do, and hence which sectors are open for investment and trade (Hufbauer et al. 2012: 5-7, 35-37). This would therefore be the preferred choice of the EU services industry.

In this approach, each country compiles a list of restrictions on the existing measures (also called Annex I) and another list of restrictions on future and sensitive measures (Annex II). Furthermore, most of the recent trade agreements that have used the negative list approach list the restrictions in financial services in a separate annex (Annex III), with the restrictions on existing measures in financial services in a Section A, and the restrictions on future measures in a Section B. Everything that is not listed is considered open and unrestricted. The listed restrictions are called 'non-conforming measures', as they do not conform to the norm of being liberalised.

The standstill and ratchet clauses, that prevent the signatories from implementing protectionist measures and that bind any measures implemented by the signatories that goes beyond what was agreed on in the agreement, are tools that ensure spreading of trade liberalisation on a non-discriminatory basis, once a party has unilaterally decided to open up the market. They fully respect the democratic control, and allow avoiding the necessity to renegotiate out-dated agreements. 
There, the participation of all administrative levels of the signatories would be a sine qua non condition to the use of the negative list. Since this list is much more exhaustive than the positive list, it requires a clearer view of what can or cannot be done at Australian sub-federal level and at EU member state level. Not involving the signatories at sub-federal levels would result in a great lack of transparency and could lead to situations in which local entities could refuse to comply with the text of the agreement (Kukucha 2015).

\section{Going beyond TiSA in all modes of EU-Australia services trade}

A major issue with services trade is that services are heterogeneous and intangible. It is therefore relevant that the EU-Australia FTA ensures that the parties will take substantial commitments that apply to all possible modes in which services are supplied. GATS identifies four modes of international services trade (UNStats 2010: 3-5).

Firstly, a mode of delivery in which neither the supplier nor the client moves across borders, but stay in their respective countries. The EU and Australia will have to make particular significant efforts in taking new commitments in this type of cross-border trade of services. This mode includes shipping or other transport services. It also includes a growing range of services that are traded through electronic transmission; not only the e-commerce of goods, but also financial services and architectural services, etc. There is a huge undiscovered potential to increase the crossborder trade of such services through ICT advances. An EU-Australia FTA would be a real opportunity to go beyond what has been done so far in identifying and addressing the issues in this services delivery mode.

The commitments related to this category may also include transactions that require the consumer to move to the country of the supplier, which is the second mode of delivery identified under GATS. It typically includes tourism, travel, education and, increasingly, health services. Arguably, there are very few remaining barriers in this mode of supply, but the FTA will be an opportunity to identify those and resolve ways to remove them.

The third mode of delivery involves the establishment by the service company of a commercial presence in another country through FDI. This is a preferred route for services companies to undertake international 
activities. Companies using this delivery mode generally need to establish a physical presence in another country in order to be able to transact with clients on a face-to-face basis. Contrary to the production of goods, the services are often produced at the same time that they are delivered to the consumer. It is crucial, therefore, for many services companies to have direct contact with their customers. A wholly owned or jointventure subsidiary, or possibly a branch that is controlled by headquarters, generally serves this purpose.

The FTA will have to ensure that the companies that would wish to use this mode of service delivery are able to establish a subsidiary in any legal form that they see fit for themselves, and also that firms are able to own and control their foreign establishments, which would involve the removal of all equity caps. A particular aspect of this mode of service delivery is that after access to the market is granted, the activity of the subsidiary company will, in the vast majority of cases, be accounted for in the GDP of the host country, rather than the host country's data on international services trade. The only data that are accounted for in international trade under this service delivery mode are the eventual profits that are repatriated to the parent firm in the home country. The initial inflow of capital to create a greenfield establishment or to acquire or merge into an existing local firm is calculated as an inflow of FDI. Nevertheless, the guarantee of market access needs to be provided for in international trade agreements.

With the 2007 Lisbon Treaty, the EU members granted new supranational competences to the EU in the area of FDI, starting in 2009 (Meunier 2014). Hence, FDI issues can now formally be negotiated with the EU in the context of FTAs. Nevertheless, there is limited precedent for negotiation partners in this respect. Pre-market access FDI by services companies was actually already part of the EU's competence through its responsibility for trade policy. And even before the Lisbon Treaty came into force, the EU had negotiated pre-market access commitments for FDI in non-services sectors. Particularly, the 2008 EU-CARIFORUM Economic Partnership Agreement included such commitments. However, it does not cover the protection of investments, post-market access. The FTAs that the EU negotiated before the Lisbon Treaty—such as those with South Korea, Columbia, Peru and six Central America nationsdo not include an investment protection chapter at all. In other words, should companies from such countries encounter a problem of market 
access in the EU, the only way for them to seek redress is to hope that the government of their country of origin is willing to spark up the state-tostate dispute settlement specified in the relevant FTA.

On the other hand, the EU member states have now granted-through new or revised mandates-negotiating power to the EU on foreign investment protection in the context of the concluded agreements with Canada and Singapore, and for the ongoing negotiations with the Association of Southeast Asian Nations (ASEAN) countries (Vietnam, Malaysia, Philippines, Thailand), with India, and with USA and Japan. Consequently, there is little doubt that the EU-Australia FTA will include an investment protection chapter, covering pre-market access commitments as well as post-establishment protection.

In addition, before the Lisbon Treaty, FDI protection was the competence of the member states of the EU. The current EU member states themselves have concluded over 1,400 bilateral investment treaties (BITs) of highlevel protection since the end of the 1950s (UNCTAD 2015). Australia has signed $21 \mathrm{BITs}$, including five with relatively new EU member states (Czech Republic, Hungary, Lithuania, Poland and Romania). Investment is about trust. Investment protection, including the right to defend it through a neutral dispute settlement, provides that trust. Most of these existing 1,400 BITs include an ISDS mechanism. There is a clear positive correlation between the volume of investment and the presence of an FTA and a BIT, and to a lesser extent of an ISDS mechanism (Berger et al. 2013). Investors take a decision to invest knowing that, should there be a problem with their investment, there is a means of redress. Hence, BITs and ISDS are an integral part of the trust that investors require in making investment decisions.

The competences between the EU and its member states in terms of FDI and BITs are still fluid (Burgstaller 2011). Nevertheless, it will be vital that discussions about the EU-Australia FTA include highlevel investment protection with a neutral, binding and efficient ISDS mechanism. This mechanism is likely to include some reforms, notably new transparency obligations. The question of ISDS is of great sensitivity within the EU (Burgstaller 2014), and possibly Australia as well, and further public debate may have the advantage of making the process more accountable to the public. This may need to be taken into consideration in the process towards an FTA. 
The fourth mode for supplying a service involves the temporary movement of natural persons associated with a services company from one country to another. It includes both the independent services suppliers and the employees of foreign services suppliers. Provisions facilitating the issue of the mobility of the services suppliers should have a key priority in the EU-Australia FTA. 'Talent mobility', or the mobility of highly skilled business personnel, is a key component of the daily activities of services companies (OECD 2008). Commitments to facilitate mobility and expedite business visas and work permits are a matter of high importance to internationally active service providers. The FTA should cover temporary movement only, rather than permanent migration.

Migration policy is not a full competence of the EU, and decisions for granting visas and work permits are taken at the member state level. However, some progress has been made within the EU among some countries with the establishment of the so-called Schengen Area in 1995, which now covers 26 European countries (including non-EU members, such as Switzerland). As a consequence of this agreement, movement of residents across these countries is now entirely free, although recent terror and refugee-related events are imposing challenges on the Schengen Area. However, this freedom does not apply to third countries and negotiations of GATS Mode Four commitments (movement of natural persons) are a first step to facilitate greater legal access for business travellers. The commitments taken by the EU under this service delivery mode are divided into the following four sub-sections: (i) movement of business visitors; (ii) movement of intra-corporate transferees/employees; (iii) movement of a services supplier to a client in the host country under the terms of a contract between two companies (contract service supplier); and (iv) movement of an independent services supplier in contract with a company in the host country.

Firstly, in terms of intra-company transferees across borders, the EU's 2014 Intra-Corporate Transferees Directive should be of great interest to Australia. Together with several directives that aim to simplify procedures, and also the so-called 2009 Blue-Card Directive, the 2014 Directivedespite imperfections (Schmitz 2015) —should offer new opportunities for an Australian services firm to dispatch its personnel to supply services across different EU member countries before returning home. 
The conditions allowing for an intra-corporate transferee should be that the natural person must have worked within the company (juridical person) for at least one year, and that they are only transferred temporarily in the context of the provision of a service through a commercial presence in the territory. Entry and stay in the EU should be limited to a maximum of three years for managers and specialists (with some longer periods in some EU countries) and of one year for trainees. Intra-corporate transferees should not be submitted to any economic needs tests, limits or quotas.

Secondly, the conditions allowing for contract service suppliers into the EU must be that the person is employed by a company (juridical person) that has no commercial presence in the EU; that the company has obtained a service contract for a maximum period of 12 months from a final consumer; that the person has worked for the company for at least one year before the contract; and that the person possesses a university degree or the required technical and professional qualifications, and has at least three years of professional experience in the sector. Where the degree or qualification has been obtained in a third country, an EU member state may evaluate whether this is equivalent to a university degree required in that member state.

Replicating GATS, the EU has allowed professional service suppliers from several partner countries to be contracted for transactions on a bilateral basis.

These 'contract service suppliers' are restricted to legal services, accounting and bookkeeping, taxation advisory services, architectural services, urban planning, engineering services, integrated engineering services, computer and related services, research and development services, advertising, management consulting services, services related to management services, technical testing and analysis services, related and technical consulting services, maintenance and repair of equipment in after sales of afterlease services contracts, translation services, construction services, site investigation work, higher education services, environmental services, travel agencies and tour operator services, entertainment services, and services related to the sale of equipment or to the assignment of a patent.

Of course, these sectors are the result of bilateral negotiations, and might either be extended or restricted, depending on the reciprocity that will be granted by the partner country to EU service providers. Commitments 
might also be subject to the application of a numerical ceiling (i.e. a minimum quota, but without a fixed cap) that will be determined during the negotiations.

\section{Going beyond TiSA: EU-Australia public procurement}

The FTA should also provide comprehensive market access to public procurement of services, with low thresholds and substantive coverage of all public institutions and entities, committing the partners to remove any discrimination in the tender process by any EU or Australian firms. It is of crucial importance to increase access for services companies to all public entities that use public procurement processes. This is obviously true for construction and construction-related professional services, such as architectural and engineering services, and urban planning. But on a daily basis all public administrations and entities also purchase telecommunications and ICT services, insurance and banking services, transport and logistic services, cleaning and catering services, legal and accounting services, and so on.

The FTA negotiations could generate considerable gains in public procurement, given that Australia is only an observer of the international Agreement on Government Procurement (GPA), not a signatory. It is currently negotiating its accession to the GPA, and it is not clear when this process will come to a conclusion. It must be emphasised, however, that this accession should not be seen as the end of the road for Australian FTA negotiators, because their EU counterparts are likely to insist on commitments beyond the GPA from Australia.

Australia is a federal state composed of sub-federal entities. Although this is likely to be a 'balancing act' (Sheffler 2015), negotiators should ensure that all the provisions apply not only at the federal level, but also to the sub-federal levels (states and territories).

The EU public procurement directives have, over the years, opened up the public procurement markets across EU member states, and have established transparency and process rules that opened up public procurement in the EU. The EU is the GPA party that has the most significant package of commitments, but it has also kept some domains exclusively reserved to EU member states or to partners of recent FTAs 
who agreed to open their markets beyond the GPA. This has been the case for Canada (Kukucha 2015), and it could therefore also be the case for Australia.

For example, the EU has not just opened up 'government' procurement only, but has opened up 'public' procurement more generally. This includes all public entities that are using procurement processes for their daily operations-from provinces, counties and municipalities to public schools, universities and hospitals. This is clearly an issue that will be put forward in the EU-Australia negotiations. Some aspects may then already be covered by Australia's GPA commitments. Nevertheless, the added value of the FTA could therefore be the reduction of the thresholds at which companies from either trade partner will be allowed to participate in tender processes of public entities in general.

As a minimum commitment, the EU will likely require Australia to allow upfront that all European companies already established in Australia and hence incorporated as an Australian enterprise should be treated as domestic companies and granted an automatic right to participate in tender calls of all Australian public entities. This is a proposal that the EU has also carried into the ongoing TiSA negotiations.

\section{Going beyond TiSA: Regulatory disciplinary arrangements and other rules}

To be effectively a deep and comprehensive FTA that embraces all new elements of 21st-century trade deals, the EU-Australia FTA would have to go beyond the traditional market access commitments. For example, beyond the traditional commitments on public procurement, as mentioned. But to become an agreement that sets a really new benchmark for others to consider, the EU-Australia FTA will also have to deal with beyond-the-border issues. Here we will not discuss the provisions that are likely to tackle labour and environmental rules in the sustainable development chapter of the FTA, although labour provisions will also have an impact on services companies, which are together by far the biggest employers in the EU and in Australia. Instead, we will analyse the obligations that both parties will have in relation to discrepancies in domestic regulation, as well as other 'horizontal' rules such as cross-border data flows. 
The FTA should include a strong horizontal chapter with disciplinary provisions for domestic regulation. This chapter should establish obligations that go beyond the rules that could be adopted in the context of the WTO's post-Bali 2014 work programme, or in the TiSA agreement, which will essentially establish basic rules for better transparency in licensing and qualification procedures. Such a chapter of the FTA should be divided into two sections: one on regulatory coherence and one on regulatory cooperation. A concrete example might be envisaged in the area of mutual recognition of qualifications of some professional services (Kerneis \& Prentice 2011).

Principles such as regulatory transparency, prior consultation with stakeholders before adoption of new or revised rules, impartiality and due process with regard to licensing and qualification requirements and procedures, and a right of appeal are already normal practice in Australian and $\mathrm{EU}$ jurisdictions and are part of most of their respective recent bilateral trade agreements. These regulatory principles and practices should be applied systematically in the FTA at all levels of the market regulation, to help limit the degrees of regulatory divergence in the future.

The relevant chapter should therefore include an impact assessment mechanism. Both the EU and Australia already use this classical 'better governance' principle at home (Dunlop \& Radaelli 2015; Kupiec 2015). Before adopting a new regulation or revising an existing legislation, the relevant regulatory body must conduct an impact assessment study of the new proposed rules to evaluate their potential impact on the targeted market, on the economy in general, on labour and the environment, and on the public budget.

In 2014 the EU started a process to revise its own rules so as to make them more efficient, suggesting that impact assessments should be made not only at the beginning of the drafting process, but also at the end of the legislative process, since the proposal might have changed in the meantime. It is likely that the EU will propose similar processes for inclusion in the EU-Australia FTA to establish the potential and actual impact of regulatory activities on bilateral trade. The purpose will be to establish a mechanism for information exchange between regulating agencies in sectors in order to increase transparency and inform possible changes to achieve better regulatory coherence. When implemented, the process should, for instance, provide full transparency about the licensing 
requirements and procedures, particularly the objectives of the regulator, obligation proportionate to the goal, least burdensome administrative costs as possible, short and predefined delays, right of appeal, etc.

Closer regulatory cooperation could be important to progressively achieve a more integrated international marketplace as well as to ensure that both trade partners together promote the development of international regulations applicable to all economic sectors. Changes towards greater regulatory coherence is a necessary first step, but the ultimate goal will be the reduction of unnecessary costs associated with regulatory differences by promoting greater compatibility through equivalence, mutual recognition or other agreed means. The outcome would be avoiding the cost of double licensing, double certification, double qualification procedures, etc.

Apart from accommodating the principles in the FTA, implementation would require sector-specific regulators of both trade partners to meet with their counterparts and exchange views on the respective objectives and methods of regulation. This may facilitate in some instances the identification of procedures that instil mutual trust and provide a basis for the authorisation of equivalence or the mutual recognition of the authorisation process of the trade partner.

To allow such a result, the horizontal regulatory cooperation chapter in the EU-Australia FTA could establish a mechanism whereby the regulators would agree to meet and exchange. The regulators will remain independent. They will not be subject to any obligations as a result. It may be appropriate for such a chapter not to be subjected to the dispute settlement system in the FTA, but to impose an obligation of cooperation on the regulators in case an issue of mutual interest is identified. The regulators could establish an annual or pluri-annual program, report on the progress of their discussions, and provide explanatory notes. In this way, the chapter will establish a living process that would put into place a regulatory cooperation mechanism on a long-term basis with the aim of achieving regulatory compatibility.

The FTA could also include sector-specific disciplinary provisions that could be included either in the sector-specific chapters of the FTA, such as telecommunication services or financial services, or in sector-specific annexes attached to the horizontal regulatory cooperation chapter. 
All specificities should indeed be taken into consideration; the regulators themselves are better positioned to set up specific arrangements as they would see fit for their own sector.

One example where regulatory cooperation could lead to concrete results is in the domain of professional services (Kerneis \& Prentice 2011). Even full market access and national treatment commitments in the FTA in all areas of professional services-including in allowing temporary movement of professionals in regulated professions, such as architects, lawyers, engineers, accountants and auditors-will not result in substantial increases in bilateral trade if service providers are forced to re-qualify before being able to provide services across borders.

The EU-Australia FTA, through regulatory cooperation provisions, could put in place a mechanism encouraging and enabling the regulators of these sectors to achieve-when there is a mutual demand from the professional bodies-mutual recognition agreements (MRAs) in professional qualifications in an EU-Australia FTA. They could, for instance, follow the example set in the EU-Canada CETA. Research shows that mutual recognition in the 2005 Services Directive enhanced services trade in the EU (Nordå 2016). A similar effect may be possible in the EU-Australia context. While the EU Treaty gives full competence to EU institutions on all external aspects of the internal market, including on professional qualifications, the EU still needs to find a way to reconcile its authorities in the areas of professional services (shared by the DG GROW, relevant member state ministries, and professional bodies), and of the international trade (shared by the DG TRADE, the Trade Policy Committee comprising member state trade representatives, and the European Parliament). ${ }^{3}$

For many years, the private sector in the EU was expected to work on the details of mutual recognition in professional services via 'profession to profession' agreements, which would then be examined by the relevant regulatory institutions of two trading partners, before becoming an annex to a binding international treaty. But this was not that easy, and some MRAs finalised by private sector organisations in the areas of architecture services were never implemented due to the lack of coordination across all involved parties.

3 DG GROW is the Directorate-General for Internal Market, Industry, Entrepreneurship and Small and Medium-sized Enterprises of the European Commission; DG TRADE is the DirectorateGeneral for Trade of the European Commission. 
With the framework agreement that is part of CETA, the European Commission and Canada have found a way forward. It describes the modalities of how MRAs on sector-specific professional qualificationsonce concluded by the private sector together with the 'licensing bodies'will finally be transformed into the binding international treaty, i.e. CETA (Sosnow, Kirby \& Stephenson 2014: 255). All the competent authorities in the member states and the provinces have been involved in reaching this solution.

Thus, the framework agreement is an enabling tool containing guidelines for the services sectors that ensure legal security to the agreement, ifand only if - the professional services sectors want to conclude an MRA. Even though CETA is not yet in force, the associations of architects have already started to work on an MRA. This model reveals quality and efficiency and it could be followed in the EU-Australia negotiations. It is, however, important to emphasise that such a model can only be relevant if all administrative levels of the signatories-that is to say the EU member states and the Australian states and territories-are involved.

Finally, the FTA should include other disciplinary provisions that are of cross-sectoral nature, but that will have a direct impact on the services companies. These rules should reflect what is already under consideration in other trade agreements, such as the TPP or the TTIP, as well as possibly the TiSA, since they should contribute to establishing international standards.

Although cross-border commercial data flows are a very sensitive subject in the EU, they are the real backbone of the digital economy, and important to sustaining growth of output and employment in all sectors of the economy, including small and medium-size enterprises (Meltzer 2015). The EU-Australia FTA will have to include rules on cross-border data flows. The commitments taken on this issue should be applied across all services sectors, including financial services. Any exceptions to these provisions would have to be limited to legitimate public policy objectives and only in full compliance with the provisions of GATS covering data privacy (GATS Article XIV). With the objective of enhancing trust of users and certainty of companies, and thus trade in goods and services, it is essential that firms comply with data protection and security rules in force in the country of residence of the data subjects. 
Nevertheless, the FTA should seek to ensure that cross-border data flows are not limited by a requirement to establish a local presence; with only few mutually agreed and well-justified exceptions. The parties should allow cross-border data flows without the requirement of locally based servers. The obligation to use local infrastructure or to establish a local presence should not be required as a condition for supplying data services. Preferential treatment to national suppliers should be prohibited in the use of local infrastructure, national spectrum, or orbital resources. Finally, the EU and Australia should ensure that local infrastructure used to convey signals on electronic communications networks is made available to services suppliers under fully non-discriminatory terms and conditions.

Lastly, the agreement should look at stating specific rules to ensure that the competition legislation also applies to state-owned and state-sponsored enterprises that compete in commercial markets. These rules could be part of the provisions in the competition chapter of the agreement. Consideration could be given to the EU regime on state aid. It imposes obligations of transparency on state-owned companies in EU member countries. It also ensures that the companies have transparent accounting rules, and it prohibits any cross-subsidisation transfers between different departments of a state-owned firm.

\section{Conclusion}

Services are an important and growing part of bilateral EU-Australia trade flows; they now account for close to 40 per cent of total trade flows between Australia and the EU, significantly higher than the 1990s, and higher also than the 20 per cent share of services trade in global trade flows. Against this background, both the EU and Australia can be expected to commence FTA negotiations with high ambitions on both market access and regulatory cooperation. The starting point for FTA negotiations on services would have four elements: (a) the 1994 GATS, supplemented by the current TiSA negotiations under WTO auspices in which both the EU and Australia are active participants; (b) the plurilateral GPA on government procurement within the WTO, which Australia is currently negotiating access to; (c) the EU-Canada CETA, which is currently considered the trade liberalisation benchmark for an FTA with the EU; and (d) the Trans-Pacific Partnership (TPP), which was signed in Auckland in February 2016 and to which Australia is a party. 
An ambitious FTA outcome on services between Australia and the EU would go beyond TiSA by providing pre-establishment access for investment capital in all sectors without restriction, and post-establishment investment protection through an ISDS mechanism. An ambitious EUAustralia FTA should also go beyond the GPA and CETA by opening up access to public procurement tenders and contracts issued by sub-federal and regional governments and by removing all equity caps in inwards investment.

Strong regulatory cooperation powers and the pursuit of greater regulatory coherence through mutual recognition, and the recognition of differing certification requirements of equivalent intent in relation to services, should also be an important feature of an EU-Australia FTA. MRAs on professional qualifications of, for example, architects, lawyers, engineers, accountants and auditors could be a significant trade-creating outcome of such cooperation. The recent EU-Canada CETA has broken new ground in this field.

Finally, an ambitious FTA between the EU and Australia should be one that encompasses two key issues. First, market access and national treatment commitments are to be taken on the basis of a negative listing, rather than a positive listing. Such an approach provides for all services sectors to be liberalised other than those reserved to an 'exceptions' list. A negativelisting approach to commitments provides for greater transparency and is more trade creating. Second, liberalisation commitments should be taken on all the modes through which international services are traded internationally, i.e. cross-border trade in services, commercial presence abroad through FDI, and the movement of natural persons.

\section{References}

Adlung, Rudolf \& Hamid Mamdouh (2014), 'How to design trade agreements in services: Top down or bottom-up?', Journal of World Trade 48(2): 191-218.

Berger, Axel, Matthias Busse, Peter Nunnenkamp \& Martin Roy (2013), 'Do trade and investment agreements lead to more FDI? Accounting for key provisions inside the black box', International Economics and Economic Policy 10(2): 247-75. doi.org/10.1007/ s10368-012-0207-6. 
Bronckers, Marco (2015), 'Is Investor-State Dispute Settlement (ISDS) superior to litigation before domestic courts? An EU view on bilateral trade agreements', Journal of International Economic Law 18(3): 655-77. doi.org/10.1093/jiel/jgv035.

Broude, Tomer \& Shai Moses (2016), 'The behavioral dynamics of positive and negative listing in services trade liberalization: A look at the Trade in Services Agreement (TiSA) negotiations', in Pierre Sauvé \& Martin Roy (eds), Research Handbook on Trade in Services (Edward Elgar: London), 385-411.

Burgstaller, Markus (2011), 'The future of bilateral investment treaties of EU Member States', in Marc Bungenberg, Joern Griebel \& Steffen Hindelang (eds), International Investment Law and EU Law (Springer: Berlin), 55-77. doi.org/10.1007/978-3-642-14855-2_4.

Burgstaller, Markus (2014), 'Dispute settlement in EU international investment agreements with third states: Three salient problems', Journal of World Investment \& Trade 15(3-4): 551-69. doi.org/ 10.1163/22119000-01504010.

Dunlop, Claire A. \& Claudio M. Radaelli (2015), 'Impact assessment in the European Union: Lessons from a research project', European Journal of Risk Regulation 6(1): 27-34.

Eurostat (2015), Eurostat online database. Available at ec.europa.eu/ eurostat/data/database.

Hufbauer, Gary Clyde, J. Bradford Jensen \& Sherry Stephenson with Julia Muir \& Martin Vieiro. (2012), Framework for the International Services Agreement, Policy Brief No. PB12-10 (Peterson Institute for International Economics: Washington, DC).

Kerneis, Pascal \& Joshua Prentice (2011), 'The European Union as a market for professional services', Australian Journal of International Affairs 65(4): 436-53. doi.org/10.1080/10357718.2011.585224.

Kukucha, Christopher J. (2015), 'Federalism matters: Evaluating the impact of sub-federal governments in Canadian and American foreign trade policy', Canadian Foreign Policy Journal 21(3): 224-37. doi.org/ 10.1080/11926422.2015.1074926. 
Kupiec, Tomasz (2015), 'Regulatory Impact Analysis practice in New Zealand in the light of models of evaluation use', Management and Business Administration 23(2): 109-28.

Meltzer, Joshua Paul (2015), 'The internet, cross-border data flows and international trade', Asia \& the Pacific Policy Studies 2(1): 90-102. doi.org/10.1002/app5.60.

Meunier, Sophie (2014), Integration by Stealth: How the European Union Gained Competence over Foreign Direct Investment, EUI Working Paper No. RSCAS 2014/66 (Robert Schuman Centre for Advanced Studies, European University Institute: Florence), December.

Nordås, Hildegunn Kyvik (2016), 'Does mutual recognition of qualifications stimulate services trade? The case of the European Union', Applied Economics 48(20): 1852-65.

Nottage, Luke (2015), 'The evolution of foreign investment regulation, treaties and investor-state arbitration in Australia', New Zealand Business Law Quarterly 21(3): 266-76. doi.org/10.2139/ssrn.2685941.

OECD (Organisation of Economic Cooperation and Development) (2008), The Global Competition for Talent: Mobility of the Highly Skilled (OECD: Paris).

OECD (2015), Trade in Value Added (TiVA)—October 2015 database. Available at stats.oecd.org/.

Schmitz, Jan (2015), 'The temporary movement of natural persons in the context of trade in services: EU Trade Policy under Mode 4 (WTO/ GATS)', in Marion Panizzon, Gottfried Zürcher \& Elisa Fornalé (eds), The Palgrave Handbook of International Labour Migration: Law and Policy Perspectives (Palgrave Macmillan: New York), 382-402. doi.org/10.1057/9781137352217_16.

Sheffler, Scott (2015), 'A balancing act: State participation in Free Trade Agreements with 'sub-central' procurement obligations', Public Contract Law Journal 44(4): 713-47.

Sosnow, Clifford, Peter Kirby \& Sean Stephenson (2014), 'The CanadaEuropean Comprehensive Free Trade Agreement and the mining sector: Key issues and opportunities', Global Trade and Customs Journal 9(6): 253-59. 
UNCTAD (2015), International Investor Agreement database (November). Available at investmentpolicyhub.unctad.org/IIA.

UNStats (2010), Manual on Statistics of International Trade in Services 2010 (MSITS 2010) (United Nations Statistics Division: New York).

Vastine, J. Robert (2005), 'Services negotiations in the Doha Round: Promise and reality', Global Economy Journal 5(4): 1-22. doi.org/ 10.2202/1524-5861.1146.

WTO (World Trade Organization) (2015), International Trade Statistics 2015 (World Trade Organization: Geneva). Available at www.wto.org/ english/res_e/statis_e/its2015_e/its15_world_trade_dev_e.htm. 
This text is taken from Australia, the European Union and the New Trade Agenda, edited by Annmarie Elijah, Don Kenyon, Karen Hussey and Pierre van der Eng, published 2017 by ANU Press, The Australian National University, Canberra, Australia. 